\title{
Mind as a Way you Love Truth: A Philosophical Appraisal of Mind by Jiddu Krishnamurti
}

\author{
Sebastian Varghese Moolayil*
}

\begin{abstract}
Krishnamurti believes that Man can come to truth neither through any organization, through any creed, through any dogma, priest or ritual, nor through any philosophic knowledge or psychological technique. He has to find it through the mirror of relationship, through the understanding of the contents of his own mind, through observation and not through intellectual analysis or introspective dissection. Man has built in himself images as a fence of security - religious, political, personal. These manifest as symbols, ideas, beliefs. The burden of these images dominates man's thinking, his relationships and his daily life. These images are the causes of our problems for they divide man from man. His perception of life is shaped by the concepts already established in his mind. The content of his consciousness is his entire existence. This content is common to all humanity. When man becomes aware of the movement of his own thoughts he will see the division between the thinker and the thought, the observer and the observed, the experiencer and the experience.
\end{abstract}

Keywords: Jiddu Krishnamurti, Mind, Love, Truth

* Lecturer in Philosophy, Dharmaram Vidya Kshetram, Bangalore, India; moolayiljanesh@yahoo.com 


\section{Introduction}

Jiddu Krishnamurti was born on May 11, 1895 in an orthodox Brahmin family of Madanapalle town in Andhra Pradesh. ${ }^{1}$ He was adopted in his youth by Dr. Annie Besant, the President of the Theosophical Society, which had its international headquarters at Chennai. Dr. Besant and others proclaimed that Krishnamurti was to be the vehicle of the World Teacher, whose coming the Theosophists had predicted. The World Teacher, according to various scriptures, takes a human form from time to time to bring salvation to humankind. The core of Krishnamurti's teaching is contained in the statement he made in 1929: "Truth is a pathless land"2 Krishnamurti gives us the idea that Man has to find the truth through the understanding of the contents of his own mind, through listening and meditation, through the mirror of relationship which provides the truth of love by inner revolution.

\section{Krishnamurti on Mind}

\subsection{Empty Mind}

According to Krishnamurti truth can come to us only when our mind and heart are simple, clear, and there is love in our heart; not if our heart is filled with the things of the mind. ${ }^{3}$ When there is love in our heart, we do not talk about organizing for brotherhood; we do not talk about belief, we do not talk about division or the powers that create division, we need not seek reconciliation. Then we are simply a human being without a label, without a country. This means that we must strip ourselves of all those things and allow truth to come into being; and it can come only when the mind is empty, when the mind ceases to create. Then it will come without our invitation. Then it will come as swiftly as the wind and unbeknown. It comes obscurely, not when we are watching, wanting. It is there as sudden as sunlight, as pure as the night; but to receive it, the heart must be full and the mind empty.

${ }^{1}$ Lutyens, Life and Death of Krishnamurti, 10.

${ }^{2}$ Krishnamurti, Truth and Actuality, 30.

${ }^{3}$ Krishnamurti, Exploration into Insight, 34. 


\subsection{Brain and Mind}

According to Krishnamurti, it is because of the brain that we are able to adjust ourselves even to unpredictable events. For the human individual, unlike the animals, the range of adjustment is unlimited and this is made possible because of the functioning of the brain. The brain does indeed an amazing feat of adjustment and this is so quietly done that we are not even aware of many of these adjustments done by the brain. For example, sugar is one of body's energy-building substances and we must have just the right amount, no more and no less. We walk a biological tight-rope between coma and convulsion, the possible results of relatively slight changes in blood-sugar levels. But the brain usually receives advance notice of impending trouble. It receives a steady flow of information about current sugar levels, and makes adjustments as effectively as a pilot guiding an airplane through a storm. If there is too much sugar, the excess is burnt up and excreted. If there is too little, the liver is instructed to release the proper amount of reserve sugar. Such controls imply the amazing power of adjustment possessed by the brain. ${ }^{4}$

It is the brain that hears and sees and it is the mind that must listen and look, not the mind that is engaged in comparison and interpretation, but the mind that is silent. The silence of the mind resides in that interval, that space between seeing and naming, between hearing and naming. It is naming which breaks the silence. Krishnamurti often speaks of the quietness of the brain and the stillness of the mind. The brain is quiet when there is no interruption in the receiving of sensorial impacts. When the flow of sensations to the brain is interrupted then is the brain rendered tense and restless. It is in the breaking up of the communication line between the senses and the brain, due to the intervention of the mind, that the brain's energies are dissipated. When the brain is able to carry on its perceptive activity without any hindrance then does it experience a calm and quiet. It is also true that when the sensorial impact on the brain is full and free then the naming process of the mind is obviously at a standstill. In the receiving of the full impact of sensations, there is created an interval between

${ }^{4}$ Krishnamurti, Exploration into Insight, 45. 
the experiencing and the naming and such interval indeed is the stillness of the mind. ${ }^{5}$ Thus, the quietness of the brain and the stillness of the mind are a joint phenomenon which means the one cannot exist without the other.

\subsection{Understanding the Contents of Mind}

Our mind is conditioned by everything we have ever experienced. It is in the nature of the mind to store these experiences into our memory. This we call knowledge. When we have to use this knowledge practically, it can be of great benefit to us, like in mechanical operations, e.g., in driving a car. But psychologically knowledge has a detrimental effect on our consciousness. For, it creates the illusion that there are definite, unchanging factors in the world which we know. But the world that is happening in front of our eyes and also the world of our mind and thoughts is forever changing and becoming. Now real knowledge can only be unchanging and everlasting. So it seems that knowledge as such is not compatible with the world it is meant to describe. Real knowledge can only be of a world that is changeless and eternal. It is very significant that Krishnamurti never spoke about such a transcendent world. He probably felt that nothing could be said about it, because it can't be an object of knowledge, perhaps because he also felt that it was more like the subject of knowledge. So he chose to negate it. In Krishnamurti's eyes a transcendent world is just another mind image. So it seems that in metaphysics he more or less took the stance of Buddhism: all leads to emptiness (sunyata). But Krishnamurti spoke his whole life about relative consciousness and the mind. ${ }^{6}$ All his endeavours were aimed at making our consciousness pure and whole again, as it is the original nature of consciousness. Now every image, every concept, every idea and thought, every feeling and judgment, in short all content of mind in its particularity, is only just a part of a greater whole. It is in all of its particularity splitting up consciousness and objectifying it, through linking it with specific content. In that way our consciousness becomes limited and relative.

${ }^{5}$ Krishnamurti, Exploration into Insight, 56.

${ }^{6}$ Yayakar, Fire in the Mind: Dialogues with Jiddu Krishnamurti, 75. 


\section{Mind and Love of Truth}

Krishnamurti uses the term 'philosophy' in its etymological sense of the 'love' of 'truth'.7 To him, philosophy is not a series of theories about life, man and the world. It is not a bundle of ideas, opinions and conclusions. Nor is it the academic discipline of conceiving, criticizing and interpreting concepts. Philosophy is not the speculative or the intellectual activity of system-building. It is not a logical analysis of language and meaning. On the contrary, philosophy, according to Krishnamurti, is the love of truth. ${ }^{8}$ Love means the instantaneous perception. It is understanding which is beyond the intellect. Truth means the life which is undetermined by thought. It means the mind which is unconditioned. Philosophy is living life independently of systems, images, ideals and beliefs. It is living from moment to moment in the total freedom of the mind. It is living in the 'present'. True life is what is happening at this instant. It is not what thought or intellect conceives it to be. Krishnamurti observes that philosophy is the understanding of the truth which is beyond the reality of thought. Philosophy is the ending of the illusion of mistaking reality for truth. It is the realization that reality can never become truth. Philosophy is the actual cessation of the ignorance and the irrationality of approaching truth through reality. Furthermore, it is understanding the finitude of reality and going beyond. Krishnamurti says:

"Philosophy means love of truth, not love of ideas, not love of speculation... And that means you have to find out for yourself where reality is and that reality cannot become truth. You cannot go through reality to come to truth. You must understand the limitations of reality which is the whole process of thought."9

${ }^{7}$ Krishnamurti, Question and Answers, 123.

${ }^{8}$ Krishnamurti, Question and Answers, 125.

${ }^{9}$ Krishnamurti, Question and Answers, 127. 


\subsection{Reality and Truth}

Krishnamurti distinguishes between reality and truth. Reality is thought which the movement of the past is. It is a psychologicalmaterial process. It is necessarily conditioned by a thing or an idea. Thought is always of something, gross or subtle, physical or psychological. It is never independent. Independent thought is a contradiction in teens. Reality is all that is conceived by thought. Reality, as Krishnamurti puts it, "comes from 'res' and that anything that thought operates on, or fabricates or reflects about, is reality."10 According to Krishnamurti, the mind or the consciousness with its thought content is reality. The content comprises the factual as well as the psychological knowledge. The factual content is the knowledge which is reasonable and useful for the biological well-being of humankind. It includes the scientific, the technological, the semantic, the numerical and the historical knowledge or information, whereas the psychological content is a messy conglomeration of the irrational and fictitious knowledge. It consists of the illusions - beliefs, hopes, images, symbols - invented by thought as a means of escape from the inward poverty, the psychological insecurity. The psychological content constitutes the mind which is conditioned, fragmented, self-centred, selfcontradictory, conflicting, confused, anxious, insecure, jealous, aggressive, corrupt, violent, war-like, crooked and insane. Krishnamurti does not condemn human reality to its psychological structure which is superficial and acquired. The psychological content is only the name and form and not the true nature of humanity. Regeneration is the understanding of the truth which is the emptiness of mind. Truth is the mind which does not contain a 'thing' put together by thought. It is freedom which is totally independent of thought. It is the mind which is devoid of the content of division, contradiction, conflict and so on. It is the mind which is whole and sane. Truth is 'nothing'. It is the mind which is no-thing or nothingness. 


\subsection{Truth is a Pathless Land}

The core of Krishnamurti's philosophy is contained in his statement that truth is a pathless land. ${ }^{11}$ It consists in his concern of setting man unconditionally and absolutely free. To him, the understanding of truth is independent of religious institutions and methods. Conforming to spiritual organisations is an impediment to the understanding of truth. Truth cannot be perceived by professing a particular faith. Truth is not a fixed thing. It does not have a predetermined path. Nor does it have a direction. Truth is neither in the past nor in the future. Truth is in the living 'present', the 'now'. And the understanding of it is immediate and direct. Paths or systems involve time. They only condition the mind, according to their pet and patent ideas. They programme and 'industrialise' the individual. They can never liberate the mind completely. Total and ultimate liberation is possible only when the mind is entirely independent of all paths. Krishnamurti says:

"I maintain that Truth is a pathless land, and you cannot approach it by any path whatsoever, by any religion, by any sect... If an organisation be created for this purpose, it becomes a crutch, a weakness, bondage, and must cripple the individual, and prevent him from growing, from establishing his uniqueness, which lies in his discovery for himself of that absolute, unconditioned Truth."12

Communication of truth is not a matter of one giving to another. The division and the image as the one who knows and the one who does not know preclude communication. Communication of truth is possible only when the speaker and the listener meet on the same level at the same time and with the same intensity. It requires a mind which really says, 'I don't know'. A mind with knowledge ideas, opinions, and conclusion can neither understand nor communicate the truth. Truth cannot be monopolised. It cannot be possessed and bartered. Truth can only be shared. Dialogue is the best means of communication. Krishnamurti says: "I think the idea of the teaching and the taught is basically wrong, at least for me. I

${ }^{11}$ Krishnamurti, Truth and Actuality, 30.

12 Krishnamurti, Truth and Actuality, 45. 
think it is a matter of sharing rather than being taught, partaking rather than giving and taking."13

\subsection{The Art of Listening to the Inner God}

To find out what is true we must never accept, we must never be influenced by what the books, the teachers or anyone else may say. If we are influenced by them, we will find only what they want you to find. And we must know that our own mind can create the image of what it wants; it can imagine God with a beard, or with one eye; it can make him blue or purple. So we have to be aware of our own desires and not be deceived by the projections of our own wants and longings. If we long to see God in a certain form the image we see will be according to our wishes; and the image will not be God. If we are in sorrow and want to be comforted, or if we feel sentimental and romantic in our religious aspirations, eventually we will create a God who will supply what we want; but it will still not be God. ${ }^{14}$ So, our mind must be completely free, and only then can we find out what is true by the art of Listening to the inner God not by the acceptance of some superstition, nor by the reading of the so-called sacred books, nor by the following of some guru. Only when we have this freedom, this real freedom from external influences as well as from our own desires and longings so that our mind is very clear - only then is it possible to find out what God is.

\subsection{A Transformed Mind in Listening}

Krishnamurti's philosophy is not a consistent system. He has not presented it in the form of a treatise. Truth eludes systems and treatises. Krishnamurti has offered his philosophy in the form of talks, dialogues and discourses he had with people of all walks of life - intellectuals, scientists, politicians, psychologists, philosophers and the common man. His talks, dialogues and discourses are the inward journeys into the actuality and the truth of oneself and the world. Through them he merely pointed out the truth to others. He never considered himself a 'guru'. He did not act as an authority. He rejected following and devotion from people. Believing truth

${ }^{13}$ Krishnamurti, Truth and Actuality, 55.

${ }^{14}$ Lutyens, Life and Death of Krishnamurti, 89.

80 
without understanding leads to misery. He asked those who wanted to understand him or the truth to be free from him. He advised to use him as a 'crutch'. To him, listening is more important than teaching. Attentive listening without the image about oneself and the speaker is necessary for understanding the truth. Listening to Krishnamurti, without choice, brings about a radical change in the mind, in the brain cells. Transformation is possible in the very act of listening. He said: "If you listen to me, which is your transformation, that listening is listening to truth."15

\section{A Transformed Mind Merges the Boundaries}

Throughout history people have always tried to make this world a better place to live in. They wanted love, peace and prosperity. But they have not succeeded in making fundamental changes come about. For even today, this world is still a place full of hatred and cruelty, full of envy and competition. According to Krishnamurti, this will always remain the case, if man doesn't want to make a complete transformation in his own consciousness. For every outer revolution or social reform only alters the outward aspects of the culture, but it does not affect the ground cause of all the problems in the world: man himself. So if there are to be some lasting changes in this world, then we need a total new man to do the job. Now science, psychology, philosophy and the arts have tried to change man, but they have not succeeded. ${ }^{16}$ They only have replaced one belief system with another, one set of knowledge with another type of knowledge. They have not changed the human being fundamentally and existentially. All changes in man occurred at the surface, but there was no deep fundamental revolution brought about in the inner world of man. For this can only be done by man himself, by becoming very sensitive and very conscious of everything that goes on inside of him. He himself has to become aware that he is thinking with second-hand knowledge, feeling with second-hand feelings, out of memory of a dead past, and always in images that he is taking for granted. For the living reality of existence is always new, but man's thought is a dead thing, not

${ }^{15}$ Lutyens, Life and Death of Krishnamurti, 125.

16 Williams, Jiddu Krishnamurti: World Philosopher, 45. 
in contact with this living reality. So man can only become loving and peaceful if he will totally free himself of the past. He has to make his thought totally empty of all knowledge and all habits. He has to let go of all images. For they are not his own. The only living reality inside of man is totally free, totally calm, and totally empty. It's a perfect love and stillness beyond words. If he manages to free himself, then he will become this one living reality that in fact transcends all of his thoughts, feelings and habits.

\subsection{True Freedom through a Transformed Mind}

If we want to be happy and totally fulfilled we need to be free. For only in true freedom can our consciousness work in its natural form. Our mind needs to be free from all images, from all concepts and ideals. But outside authorities have influenced the mind and moulded it. It's been formed by everything around us, especially by forces we ourselves gave credit to. So the mind has been formed by our parents, by our teachers, by our preachers, by our politicians, by everybody who wanted to assert their control over us. And we listened to them, because we thought they could teach us the truth about our selves and the world. But they have put all sorts of images in our mind and we have become the prisoners of these images. Because of these images we are not free anymore to reach the truth that lives by itself in our own consciousness. So Krishnamurti denied all authority. He often said that we have to look for our selves in finding the truth. Often in his speeches he said 'the speaker is not the authority' or 'are you investigating it on your own?' with a poignancy on the verge of aggression. ${ }^{17} \mathrm{He}$ did not want followers in some sort of a belief system, but he wanted fellow explorers. He wanted us to be open and unprejudiced. That's why he denied all forms of outer religion too. Religion presents the believer with a definite view of God that is taken over by the mind as a mere concept. And so it becomes a dead thing, obstructing our experience of the living reality. God, faith, belief etc. are nothing more than images of the mind. And we have to totally free us of all these images. In this denial of all religious belief and dogma Krishnamurti is labelled a Buddhist. He is

17 Goleman, Krishnamurti's Choiceless Awareness: The Varieties of Meditative Experience, 45.

82 
compared to the Buddhist philosopher Nagarjuna in denying all content of mind. There is only sunyata, formless emptiness, in consciousness. But he also denied all these comparisons.

Criticism: Krishnamurti's point of view leads to some sort of a double bind. For when we state 'true freedom is to be free from all authority' we imply that this is the truth, even if we accept this as a mere relative truth, even if we remain open to all sorts of objections and ameliorations. ${ }^{18}$ With this implication of telling the truth we have become authoritive, if we like it or not because if it is the truth, then it will have a tremendous power to convince. This is the case with every proposition of this kind. The problem is not of authority, the problem is the rigidity of authority. True scientific authority remains always open to falsifications, for a better truth is always to be looked for. But it is in the nature of language to be authoritive. Krishnamurti was, I think, aware of this problem of language.

\subsection{Inner Revolution of the Mind through Love}

Regression of the mind is the regeneration of the society. The society we live in is not different from the nature of our mind and the quality of life. It cannot be different from the individuals who constitute it. As is the mind so is the individual. As is the individual so is the society. Society is the relationship of the individuals. Mind is the basis of the relationships. The psychological structure of the individuals constitutes the society. Society is the spectacular manifestation of the mind. It is the outward expression of the individuals' inner being. The mind and the society constitute a single movement, like the ebb and flow of the wave. The actual content of them is one and the same. The crisis in the society is the crisis in consciousness. The separation between the two is an illusion. Because consciousness is divided, the society is ridden with the problems like endless division, conflict, violence and war. Poverty, over-population, environmental degradation, nuclear holocaust are the results of the crises in the mind. Therefore the real change of the society absolutely requires the change of the

18 Goleman, Krishnamurti's Choiceless Awareness: The Varieties of Meditative Experience, 76. 
mind. Krishnamurti says: "You and the world are not two different entities. You 'are' the world, not as an ideal, but actually... As the world is yourself, in the transformation of yourself you produce a transformation in society."19

Radical change in the society cannot be brought about by any other way except by the absolute change in the mind. The mind is the centre of the society. Unless there is change at the centre, there will be no change at the periphery. Social change is not possible through ideologies, - economic, political or religious. It is not possible through the change of the governments. It does not come after a planning or a blueprint. Governmental change is no change at all. Social change cannot be effected through philanthropy either. Neither humanism nor humanitarianism can change the society radically. The timeless transformation of the mind 'through' choiceless awareness is the only way of changing the society. The realisation of the fact that there is no other way of changing the society except by changing oneself, one's mind, brings about the change in the mind. Insight into the fact that "I am the world and the world is 'me' regenerates the mind. Choiceless awareness of the quality of the relationships empties the mind of its psychological content. ${ }^{20}$ Freedom of the mind should be the foundation of a sane society. As already mentioned, the free mind is truth. Truth is love. Love alone transforms men and his society. Love is without the 'centre', the 'me'. It is 'nothingness'. For it, far is near. There is no division as mine and thine. Love is the only panacea for all the ills of the society. Krishnamurti says:

"There is only one fundamental revolution. This revolution is not of idea; it is not based on any pattern of action. The revolution comes into being when the need for using another ceases. This transformation is not an abstraction, a thing to be wished for, but an actuality which can be experienced as we begin to understand the way of

19 Goleman,Krishnamurti's Choiceless Awareness:The Varieties of Meditative Experience, 56.

20 Goleman, Krishnamurti's Choiceless Awareness: The Varieties of Meditative Experience, 167. 
our relationship. This fundamental revolution may be called love; it is the only creative factor in bringing about transformation in ourselves and so in society." 21

\section{Conclusion}

When man becomes aware of the movement of his own thoughts he will see the division between the thinker and thought, the observer and the observed, the experiencer and the experience. He will discover that this division is an illusion. Then only is there pure observation which is insight without any shadow of the past or of time. This timeless insight brings about a deep radical mutation in the mind. Total negation is the essence of the positive. When there is negation of all those things that thought has brought about psychologically, only then is there love, which is compassion and intelligence. So the free mind is truth and truth is love and love alone transforms men and his society. Therefore the real change of the society absolutely requires the change of the mind.

\section{References}

Goleman, Daniel. Krishnamurti's Choiceless Awareness: The Varieties of Meditative Experience. New York: Dutton, 1977.

Khare, Brij B. Jiddu Krishnamurti: Things of the Mind. Delhi: Motilal Banarsidass, 1988.

Krishnamurti, Jiddu. Exploration into Insight. San Francisco: Harper and Row Publishers, 1980.

Krishnamurti, Jiddu. Question and Answers. Madras: Krishnamurti Foundation Trust, 1982.

Krishnamurti, Jiddu. Tradition and Revolution. Madras: Orient Longman / Sangam Books, 1974

Krishnamurti, Jiddu. Truth and Actuality. Madras: Krishnamurti Foundation in India, 1997.

Lutyens, Mary. Life and Death of Krishnamurti. New Delhi: Srishti Publishers \& Distributors, 1990.

Williams, C. V. Jiddu Krishnamurti: World Philosopher. Delhi: Motilal Banarisidas, 2004.

${ }^{21}$ Khare, Jiddu Krishnamurti: Things of the Mind, 156. 
Yayakar, Pupul. Fire in the Mind: Dialogues with Jiddu Krishnamurti. Delhi: Penguin Books India, 1995. 